\title{
COVID-19 AND PROFESSIONAL DENTAL PRACTICE. THE POLISH DENTAL ASSOCIATION WORKING GROUP RECOMMENDATIONS FOR PROCEDURES IN DENTAL OFFICE DURING AN INCREASED EPIDEMIOLOGICAL RISK
}

\author{
Marzena Dominiak' , Ingrid Różyło-Kalinowska ${ }^{2}$, Tomasz Gedrange ${ }^{1,3}$, Tomasz Konopka ${ }^{4}$, Jakub Hadzik' ${ }^{1}$, Wojciech Bednarz ${ }^{4,5}$, \\ Jacek Matys ${ }^{1}$, Anna Lella ${ }^{6}$, Sadri Rayad ${ }^{7}$, Radosław Maksymowicz ${ }^{8}$, Amadeusz Kuźniarski ${ }^{9}$ \\ 'Chair and Department of Oral Surgery, Wroclaw Medical University, Wroclaw, Poland \\ ${ }^{2}$ Department of Dental and Maxillofacial Radiology, Medical University of Lublin, Lublin, Poland \\ ${ }^{3}$ Chair of Orthodontics, Technical University of Dresden, Germany \\ ${ }^{4}$ Chair and Department of Periodontology, Wroclaw Medical University, Wroclaw, Poland \\ ${ }^{5}$ Specialized Medical Clinic MEDIDENT in Gorlice, Poland \\ ${ }^{6}$ Individual Specialist Dental Practice in Olsztyn, Poland \\ ${ }^{7}$ Technology Transfer Dental Center sp. z 0.0. Academic Outpatient Dental Clinic in Wroclaw, Poland \\ ${ }^{8}$ Non-public Health Care Centre "DentAR" in Rzeszów, Poland \\ ${ }^{9}$ Chair and Department of Dental Prosthetics, Wroclaw Medical University, Wroclaw, Poland
}

\begin{abstract}
The recent spread of severe acute respiratory syndrome coronavirus 2 (SARS-CoV-2) and its associated coronavirus disease (COVID-19) has gripped the entire international community and has caused widespread public health concerns. Despite global efforts to control the disease transmission, the outbreak is still on a rise because of fast spreading of this infection by the community. Once in the human body, SARS-CoV-2 is abundantly present in nasopharyngeal and salivary secretions of affected patients, as it is predominantly transmitted through respiratory droplets and direct contact. Therefore, dental professionals may easily encounter a patient infected with SARS-CoV-2, and need to work with tremendous caution, preventing spreading of infection. Thus, the aim of this article was to provide a brief overview of epidemiology, symptoms, and routes of transmission of this novel infection. In addition, we present specific recommendations of the Polish Dental Association for dental practice for screening of patients, infection control strategies, and patient management protocol.
\end{abstract}

KEY wORDs: coronavirus, COVID-19, SARS-CoV-2, virus, disease transmission, infection, dentistry, recommendation.

J Stoma 2020; 73, 1: 1-10

DOI: https://doi.org/10.5114/jos.2020.94168

\section{INTRODUCTION}

SARS-CoV-2 - RNA virus, together with SARS-CoV, are betacoronaviruses, which were first identified in 2002 in Guangdong Province, China. The name is associated with a severe acute respiratory syndrome caused by coronavirus (SARS-CoV and SARS-CoV-2). A decade later, another betacoronavirus, i.e. the Middle East respi-

JOURNAL OF STOMATOLOGY CZASOPISMO STOMATOLOGICZNE

AdDRESS FOR CORRESPONDENCE: Prof. Ingrid Różyło-Kalinowska, Department of Dentomaxillofacial Radiology, Medical University of Lublin, 7 Karmelicka Str., 20-081 Lublin, Poland, e-mail: ingrid.rozylo-kalinowska@umlub.pl 
ratory syndrome coronavirus (MERS-CoV), originally identified in 2012, caused the Middle East respiratory syndrome (MERS) [1]. There is scientific evidence that this new coronavirus is similar to the coronavirus species found in bats and potentially pangolins, confirming the zoonotic nature of this new cross-species viral-mediated disease $[2,3]$. The virus incubation time varies from 0 to 24 days, making it necessary to undergo quarantine, especially if one stayed in the areas identified as particularly prone to infection [4].

In order to penetrate the cell, SARS-CoV-2 uses ACE2 receptor (angiotensin converting enzyme 2) [5] mainly affecting the lower airways [6]. Person-to-person transmission of the virus was confirmed both in hospital and family settings [7]. It is typically transmitted through respiratory droplets and direct contact. Recent reports [8], however, provide information about possible infection through fecal-oral transmission. The virus can also be transmitted from infected surfaces to the mucous membranes of the nose, eyes, and mouth $[9,10]$. Moreover, it is known that SARS-CoV-2 can bind to human angiotensin converting enzyme 2 (ACE-2) cells, which are also highly concentrated in salivary glands. This may be a possible explanation for the presence of SARS-CoV-2 in secretory saliva. This fact is particularly important as people touch their faces approximately 23 times per hour. Of all face touches, $44 \%$ involved touching the mucous membrane of mouth or nose [11]. Therefore, there is a possibility for COVID-19 transmission via aerosol or fecal-oral route, that may contribute to the infection spread in dental office [12-15].

The recently described human coronavirus ( $\mathrm{HCoV})$, strain 229E, remains infectious for 3 hours to 3 days; its viability depends on the type of material: metal, teflon, ceramics, etc. It also remains stable and capable of replication outside the host cell [16], as described below:

- in the air (aerosol): up to 3 hours,

- copper surfaces: up to 4 hours,

- ceramics and glass: up to 5 hours,

- surgical gloves: up to 8 hours,

- carton box: up to 24 hours,

- plastic and steel: up to 3 days.

On March 11, 2020, the World Health Organization (WHO) declared a pandemic of a new coronavirus, due to the rapid spread of SARS-CoV-2 and its associated coronavirus disease (COVID-19), which is a public health emergency, and the latest global death rate amounts to as much as $3.4 \%[17,18]$. According to the WHO situation report (March 16, 2020) on COVID-19, the number of reported COVID-19 cases exceeded 160,000, with 6,000 deaths globally [19], and this number is constantly growing [2]. Fast and wide transmission to another person, lack of vaccines, and targeted treatment, results in increasing demand for proven knowledge on safe dental practices during the COVID-19 pandemic.

If appropriate precautions are not taken, the dental office may potentially expose patients to cross-infection.
In response to the aforementioned data, the presidium of the Polish Dental Association, in cooperation with Stomatologiczne Centrum Transferu Technologii sp. z o.o., a non-public healthcare provider, the Academic Outpatient Dental Clinic, Wroclaw Medical University as well as external experts, prepared guidelines and algorithms for dental professionals.

The recommendations were prepared based on currently available data concerning particular specialties of dentistry, aiming to support dental professionals in choosing the best treatment strategy. However, the final decision regarding particular case should be made directly by the attending physician who is responsible for treatment and in consultation with patient or legal guardian. In addition, prior to deciding, physicians should verify the applicable rules and regulations relating to the recommendations presented. This paper is divided into recommendations concerning:

1. Procedures for outpatient clinic personnel.

2. Procedures prior patient admission.

3. Procedures related to patient admission and service requirement.

4. Security for medical personnel and preparation of the space in dentist office.

5. Procedures in the event of a reasonable suspicion of exposure to SARS-CoV-2.

\section{PROCEDURES FOR OUTPATIENT CLINIC PERSONNEL}

Whenever possible, individuals over 60 years of age or with cardiovascular diseases, hypertension, respiratory diseases, and/or diabetes mellitus are recommended to work remotely. If the remote work is not possible, it is recommended that all individuals staying in dental office should daily measure body temperature using a non-contact thermometer and submit an epidemiological declaration once a week (Appendix 1). All medical and administrative personnel of healthcare facility should be familiarized with the current procedures in a situation of increased epidemiological risk and should be trained on how to deal with a patient infected with SARS-CoV-2.

Telephone numbers of the following institutions should be placed in a visible place:

- district sanitary-epidemiological station,

- company carrying out sanitary transport of patients suspected of being infected with SARS-CoV-2 coronavirus (list available at individual voivodeship branches of the National Health Fund),

- isolation or observation-isolation ward.

It is recommended to launch extensive ICT information campaigns, including social media. Additionally, a fasttrack communication with the personnel of unit should be established in order to communicate the most urgent information efficiently and effectively by a mobile phone. 
Within the facility area, it is required to designate and mark the points, where each employee or visitor/ accompanying person should be able to wash and disinfect hands. Hand hygiene has been considered the most important element of self-defense and a critical factor of virus transmission between patients [20, 21]. Disease Control and Prevention (CDC) centers recommend regular and thorough washing of hands with soap and water for at least 20 seconds from the fingers to the wrist $[8,22]$.

In order to monitor the number of personnel staying in the facility, it is recommended to keep an entry register.

\section{PROCEDURES PRIOR PATIENT ADMISSION}

\section{PATIENT REGISTRATION}

The Polish Dental Association (PDA) recommends registration by telephone or Internet only. Personal registration is not advised. It is also advised to provide dental teleconsultations and issuing e-prescriptions, in order to minimize the number of dental patients reporting to an outpatient clinic and/or seeking treatment. The patient should only be scheduled for an appointment if it is absolutely necessary. The physician providing dental teleconsultation can issue a sick leave, based on the medical history and assessment of patient's health condition [23]. The teleconsultations should be recorded in the patient's medical record.

It is recommended to interview the patient about a basic epidemiological history during phone call, with particular emphasis on travelling abroad in the last 14 days. It is suggested that the appointment should be postponed for all patients reporting dyspnea and influenza-related symptoms including cough, elevated body temperature, and rhinorrhea. It is suggested to reschedule (over the phone) all pre-planned appointments, especially with regard to the following groups of patients considered to be at high-risk:

- patients over 65 years of age,

- patients with concomitant diseases (in particular cardiovascular diseases, hypertension, diabetes mellitus),

- immunodeficient patients.

Registration to the outpatient clinic should be done with a safety margin, so that in case of delays in service, it is possible to minimize the contact between patients while waiting for a visit. It is advised to extend time breaks between visits in order to properly disinfect and ventilate the dental office. Due to the risk of transmission of infection through paper documentation, electronic documentation is advisable [24].

\section{ENTERING DENTAL OFFICE}

Whenever possible, PDA recommends creating an isolated room at the entrance to the facility in the form of hygiene sluice. Any person entering the dental office is urged to disinfect hands. Then, the patient must un- dergo an epidemiological check-up in an isolated room. The check-up consists of 2 elements: non-contact body temperature measurement and mandatory epidemiological declaration (Appendix 1). If the medical history or temperature measurement raise concerns, the appointment should be delayed for 14 days (not applicable to life/health threatening events). For all patients presenting dyspnea and influenza-related symptoms such as cough, elevated body temperature, and rhinorrhea, a postponement of the visit should be considered, even in the absence of a positive epidemiological history. In case of underaged patients or those who need an assistance, both the patient and guardian/aide undergo the aforementioned full procedure. The patient reports with only one accompanying person. Naturally, in specific situations, it is possible to admit 2 aides of e.g. a disabled child or medical assistance of inpatient.

It is recommended to maintain a distance of at least 1 meter (WHO guidelines of February 27, 2020) [25] up to 2 meters (approx. $6 \mathrm{ft}$.) [8] between individuals staying in the same room, queue, etc.

The following scenarios should be considered in particular:

If any answer in the epidemiological history is positive, the possibility of postponing the visit should be considered and, depending on the actual announcements of the National Chief Sanitary Inspector (CSI) and the patient's health condition, it is recommended to:

1. Contact local sanitary-epidemiological station in any doubtful case.

2. Referring the patient to home quarantine for 14 days (such recommendation can be made already at the stage of registration, taking into account the Chief Sanitary Inspector's procedure of February 14, 2020) [25].

Moreover, pharmacological protection in a form of telemedical solutions of the patient should be considered such as e-consultation and e-prescription, taking into consideration references of the Polish Dental Association Working Group for administration of antibiotics in dentistry [26].

Other cases with a negative epidemiological history and with no influenza-related symptoms [27]:

1. Body temperature below $37.3^{\circ}$ - dental emergency - with no influenza-related symptoms: visit recommended.

2. Body temperature above $37.3^{\circ}$ and below $37.9^{\circ}-$ dental emergency - with no other influenza-related symptoms: medical visit recommended.

3. Body temperature above $37.3^{\circ}$ and below $37.9^{\circ}$ - dental emergency - with a presence of influenza-related symptoms: a decision of the attending physician, with regard to benefits of treatment and visit postponement.

4. Body temperature above $37.9^{\circ}$ - dental emergency - information to be provided to a sanitary-epidemiological station and proceeding in compliance with the guidelines thereof, patient's referral to an isolation institution for epidemiological verification. 


\section{DENTAL OFFICE/WAITING ROOM/REGISTRATION DESK}

Preparation of waiting room/registration desk/dental office before and after patient's admission:

1. At registration desk, it is recommended to keep a safe distance of at least 1 meter from the patient, and if possible, to use isolation from the patient in the form of transparent plexiglass panels.

2. Removal of all unnecessary objects from the dental office and registration desk, including equipment not used during dentistry procedure. Necessary equipment should be covered with disposable foils and/or dental napkins.

3. Removal of any leaflets, press, mouse mats, children's play corners, etc.

4. The use of foil covers for X-ray detectors, suction tips, dental sleeves, spittoons, lamp holders at the dental unit.

5. Each time, after every medical appointment, disinfection of flat surfaces.

6. Each time, after every medical appointment, disinfection of a computer, in particular a keyboard and computer mouse, in the treatment room.

7. Each time, after every medical appointment, thorough disinfection of a dental unit lamp.

8. Each time, after every medical appointment, disinfection of door handles, handrails, buttons, etc.

9. Sterilization of all instruments that are used inside the oral cavity, including turbine tips, handpieces, and contra-angle handpieces. Sterilization is recommended every time after patient's admission (steam sterilization: autoclave, formaldehyde sterilization, or dry heat sterilization) [6].

Disinfection procedures for objects and/or flat surfaces should be applied in the following order: wiping with disposable wet wipes moistened with a disinfectant in order not to rise up re-settled aerosol particles, and then spraying the surface again and wiping it with the use of disposable gloves. A solution of $0.1 \%$ sodium hypochlorite should be used for 1 minute (maximum 1-part sodium hypochlorite for every 9 parts water) [9].

\section{DEACTIVATION OFTHEVIRUS BY MEANS OF ANTISEPTICS}

Antiseptics containing ethanol (78-95\%) and povidone-iodine solution $(0.23-7.5 \%)$ rapidly inactivate coronavirus with high concentration (more than $4 \log 10$ ) already after 30 seconds up to 1 minute [28-31]. To effectively inactivate SARS-CoV-2 virus with sodium hypochlorite, the required minimum concentration should be $0.21 \%$ (30 seconds) $[18,28]$; at $0.01 \%$ concentrations, the exposure time should be 10 minutes [27-29]. The recently published research on coronavirus suggest the effectiveness of inactivation already after 1 minute, when $0.1 \%$ sodium hypochlorite is applied [30].

The virucidal effect of hydrogen peroxide was found for $0.5 \%$ solution and exposure for 1 minute $[25,29]$.
Chlorhexidine digluconate for $0.2 \%$ solution is assessed as generally ineffective $[30,32]$. On the other hand, its combination with alcohol definitely increases its activity, decreasing the bacterial aerosol, formed by rotary instruments, up to $9 \mathrm{ft}$. $(2.74 \mathrm{~m})$, which minimizes the infectious effect on a dentist [33].

SARS-CoV-2 basic, surface-active chemicals for virus control/inactivation [28-36]:

- Highly effective:

- ethyl alcohol - from 78\%,

- povidone-iodine solution, from $0.23 \%$,

- hydrogen peroxide, from $0.5 \%$,

- sodium hypochlorite, from $0.21 \%$.

- Less effective:

- ethyl alcohol, minimum concentration of $62-71 \%$,

$-0.02 \%$ chlorhexidine digoluconate,

- sodium hypochlorite, from $0.01 \%$.

Various ready-made products are available on the Polish market, which should provide protection against viral transmission. The following preparations are commercially available:

- Promanum Pure ${ }^{\circledR}$ - ethanol and isopropanol,

- Softasept $\mathrm{N}^{\circledR}$ - ethanol and isopropanol,

- Kodan Tinktur Forte ${ }^{\circledR}$ - propanol and isopropanol,

- Leko ${ }^{\circledR}$ injection kit - isopropanol,

- Braunoderm ${ }^{\circledR}$ - isopropanol and povidone iodine,

- Skinman Soft ${ }^{\circledR}$ - isopropanol.

The products listed above contain various active ingredients, including ethyl alcohol and isopropyl alcohol, and they are recommended for hand disinfection only. It should be remembered that hand disinfection needs to be done on dried hands, never wet (due to dilution of disinfectants), and its duration should not be shorter than 30 seconds.

Since the virus can survive on hard surfaces (plastic, polished metal-steel) up to 3 days at room temperature and humid environment, thorough disinfection of such surfaces in the office as well as keeping the air as dry as possible, is recommended [30].

In the context of asepsis, it should be known that SARSCOVID- 2 virus is thermolabile over $80^{\circ} \mathrm{C}$. This guarantees the effectiveness of the applied sterilisation process in the dental office, using steam under increased pressure.

\section{PROCEDURES RELATED TO PATIENT ADMISSION AND SERVICE REQUIREMENT}

After the initial triage of patients in the hygiene sluice, the epidemiological interview to double-check the patient should be repeated in the dental office, with possible questions:

1. Have you been to a high-risk country/region indicated by the WHO and the Chief Sanitary Inspector?

2. Have you had any contact with someone from the affected areas?

3. Have you had any contact with a known COVID-19 patient? 
4. Have you had any contact with a quarantined person?

5. Have you had a fever, cough, rhinitis, conjunctivitis, or difficulty in breathing/dyspnea?

Furthermore, special attention should be paid to the question concerning medicines taken on the day of visit. Anti-inflammatory drugs can lower body temperature, which may additionally influence a false negative temperature measurement. As part of a detailed medical history, it is necessary to ask the reason for using these drugs, e.g. toothache (which is no contraindication for urgent and accelerated admission). On the other hand, when the patient's medical history shows general symptoms that may indicate an infection, the medical appointment should be postponed, if it does not pose an immediate threat to the patient's health or life.

Physicians shall admit patients in separate rooms or at a minimum distance of $2 \mathrm{~m}$, working in shifts, so that the medical teams do not have any contact with each other. If a quarantine for healthcare personnel of a given medical team is necessary (following a contact with infected patient), a second team can ensure further continuity of patients' admissions at the facility.

Regarding procedures related to conservative dentistry and endodontics, it is advisable to use a dental dam and high-pressure suction tip, which minimize the formation of highly contaminated aerosol in the dental office.

Before starting the treatment, it is recommended to rinse the patient's mouth with $1 \%$ hydrogen peroxide solution, $0.2 \%$ povidone iodine solution, or $0.2 \%$ chlorhexidine-alcohol solution. The aqueous solution of chlorhexidine does not show any virucidal effects against SARS-CoV-2 [9].

In situations of increased epidemiological risk and reduced general access to medical care, including dental care, it is reasonable to divide dental treatments into urgent, accelerated, and scheduled.

The Polish Dental Association recommends urgent and accelerated treatments [37]:

1. Diagnosis and urgent treatment including neoplastic lesions, potentially neoplastic lesions, mucosal pain, necrotizing gingivitis, endodontic-periodontal syndrome, tooth chamber trepanation, periapical or periodontal abscess incision, extraction of a hurting tooth or a tooth causing an abscess, healthcare provision of post-traumatic patients (dental trauma to the teeth and/or soft tissues).

2. Accelerated treatments include cyst removal, emergency healthcare provision in the field of conservative dentistry (lost filling causing sharp edges of the tooth crown, a lost dressing), endodontic (lost dressing, termination of treatment), prosthetic (damage to permanent and temporary restorations), and orthodontic (loss of a bracket, damage to ligature, damage to dental arch, loss of denture retention) treatments. Conservative management should be carried out using a dental dam, thus reducing the contamination caused by the patient's saliva [8]. Recommended postponement of treatment until the improvement of epidemiological situation (until further notice)

3. Scheduled treatment (i.e. extraction from orthodontic indications, scheduled implantological treatment, scheduled prosthetic treatment, scheduled orthodontic treatment).

The above-mentioned treatments are performed most frequently and do not include all treatments performed in dental offices, particularly specialty ones. Again, each dentist, on the basis of their knowledge, should make a final decision regarding the eligibility for urgent and accelerated treatment.

What is particularly important, is the fact that the final decision on dental treatment is made by an attending physician for each patient belonging to risk groups (diabetes, therapy with immunosuppressants, etc.) after assessment of benefits and losses resulting from the initiation of the procedure or its postponement.

Taking into account the space of each facility, separation of patient groups should be considered. Urgent patients, suffering from general concomitant diseases or belonging to risk groups (over 65 years of age), should be admitted in a separate room, preferably by a designated interdisciplinary healthcare team, with reduced contact with other patients to minimize a cross-infection.

If radiological examinations are required, it is advisable to take pantomographic and/or CBCT images, and to postpone intraoral imaging due to the short distance between personnel and the patient's face during the examination, thereby contributing to higher exposure to the patient's saliva [38].

Due to the risk of transmission of infection through paper documentation, electronic documentation is advisable, including referrals, descriptions, and communication between the personnel [39].

\section{SECURITY FOR MEDICAL PERSONNEL AND PREPARATION OF THE SPACE IN DENTIST OFFICE}

Personal protective equipment (PPE) kit regarding wearing of protective clothing by healthcare employees (physicians and medical personnel) when meeting patients at risk of COVID-19 infection, on the basis of the World Health Organization (WHO) [23] and include:

1. Respiratory protection: N95 highly efficient filtering masks with FFP2 (filtering face piece 2) or FFP3 standard; in the absence of FFP2/ FFP3 half-masks, the use of ordinary surgical masks is recommended. In this case, the risk and adequacy of PPE should be continuously assessed in the context of individual patients.

Protective masks may vary depending on the region where they are manufactured, so appropriate markings should be used for the assessment of a face mask [40]:

- FFP1 and P1: at least $80 \%$ filtration of all particles that are $0.3 \mu \mathrm{m}$ in diameter or larger, 
- FFP2 and P2: at least 94\% filtration of all particles that are $0.3 \mu \mathrm{m}$ in diameter or larger,

- N95: at least 95\% filtration of all particles that are $0.3 \mu \mathrm{m}$ in diameter or larger,

- N99 and FFP3: at least 99\% filtration of all particles that are $0.3 \mu \mathrm{m}$ in diameter or larger,

- P3: at least $99.95 \%$ filtration of all particles that are $0.3 \mu \mathrm{m}$ in diameter or larger,

- N100: at least $99.97 \%$ filtration of all particles that are $0.3 \mu \mathrm{m}$ in diameter or larger.

Notes:

Since the size of SARS-CoV-2 virus is $0.06-0.14 \mu \mathrm{m}$, no face mask provides good protection against the virus in the air. However, wearing the face masks reduces the risk of airborne infection in healthy individuals; therefore, the WHO, in accordance with the recommendations of February 27, 2020 [25], advises wearing protective masks in individuals with symptoms of respiratory tract infections (cough, sneezing). In addition, it protects all patients against uncontrolled touching of their face with their own fingers.

There is no need for personnel's continuous work in protective masks nor protective suits [23].

In any case of the surgical mask's contamination, it must be replaced in accordance with safety rules.

2. Eye protection such as glasses and a face shield should be placed below the chin line [40]. Important: PPE used for eye protection should fit the user's face and be compatible with a surgical mask/half-mask used.

3. Body protection: a waterproof, long-sleeved, medical apron, and disposable caps.

4. Hand protection: standard gloves should cover the wrist and cuffs of the apron.

\section{THE ORDER OF WEARING PERSONAL PROTECTIVE EQUIPMENT}

1. Hand disinfection.

2. Wearing a disposable apron.

3. Wearing a highly efficient filtering mask.

4. Wearing a surgical mask.

5. Wearing safety goggles or a face shield (a face shield covering the face up to the chin line).

6 . Wearing gloves (gloves should cover the wrists and cuffs of the apron).

\section{PERSONAL PROTECTIVE EQUIPMENT REMOVAL}

This is a procedure that requires special attention, as infectious material may be on the outer surface of PPE. If PPE is removed incorrectly or carelessly, accidental contamination and subsequent infection may occur. After its removal, disposable equipment should be thrown into an infectious waste container immediately. Reusable equipment (e.g. a face shield), after its use, should be placed in a container for contaminated medical equip- ment and, before its next use, decontaminated according to the manufacturer's recommendation. Gloves should be removed first (after prior disinfection), in a way that minimizes hand contamination. Then, it is necessary to disinfect one's hands and put a new pair of gloves on. After putting a new pair of gloves on, an apron should be removed. For this purpose, it is recommended to grasp the back side of the apron and pull the contaminated front side away from the body, wrap it inside and roll up the sleeves outside (avoid touching the contaminated front side of the apron). Hands should be disinfected. Subsequently, the goggles/face shield needs to be removed without touching their front side, and then hands should be disinfected again. The next steps are: the face mask removal (it is necessary to grasp straps and carefully remove the face mask, making sure not to touch its outer surface), hand decontamination, removal of gloves having put on before removing the apron, and repeated hand decontamination. Individual steps for PPE removal are shown in Box 4. If an assistant is involved in removing PPE, they should also be wearing PPE (surgical mask and gloves) and follow the principle of hand decontamination after each activity when removing PPE.

PPE should be put on just before entering the patient's room and removed at a designated exit point with a container for disposable PPE and the equipment necessary for hand hygiene.

\section{THE ORDER FOR REMOVING PERSONAL PROTECTIVE EQUIPMENT}

1. Hands disinfection.

2. Glove removal.

3. Hands disinfection and wearing a new pair of gloves.

4. Apron removal.

5. Hands disinfection.

6. Face mask/shield removal.

7. Hands disinfection.

8. Face mask removal.

9. Hands disinfection and gloves removal.

10. Final washing and hands disinfection.

Notes:

If other person participates in the treatment and an aerosol is formed during the visit, they should also wear PPE (mask, apron, gloves) and the same recommendations as the physician are applied. It is recommended not to touch surfaces or objects with hands dressed in gloves that were used as a part of dental procedure. It is essential to decontaminate touched objects and surfaces. In particular, touching one's face with one's hands should be avoided.

\section{PROTECTION OF HEALTH PERSONNEL (ROOM CLEANING)}

- protective masks,

- aprons,

- rubber work gloves, 
- safety goggles,

- safety footwear.

\section{INDOOR AIR DISINFECTION}

Frequent room ventilation is the most important issue when disinfecting the indoor air; however, there should be as little movement as possible in the office, so that the bioaerosol contained is not stirred up. The air needs to be dry; no humidifiers should be applied.

The use of air purifiers with HEPA14 filters or higher, where the filtration efficiency is $99.995 \%$ or more, for particles $\geq 0.01 \mu \mathrm{m}$, which at a virus size of $0.12 \mu \mathrm{m}$ $(120 \mathrm{~nm})$ are highly effective [41-44], is recommended. UV radiation can also be used to eliminate microorganisms present in the air and on surfaces. The UV wavelength ranges from $328 \mathrm{~nm}$ to $210 \mathrm{~nm}$, with the highest antimicrobial effect spectrum ranged from $240 \mathrm{~nm}$ to $280 \mathrm{~nm}$. Dormancy of microorganisms occurs as a result of induction of thymine dimer formation and, consequently, DNA damage. UV radiation does not penetrate deeply into solids and liquids, and the effectiveness of the elimination of bacteria and viruses depends on many factors including temperature, humidity, presence of organic matter, and dust.

A prospective solution may be oxygen-ozone therapy [45]. Ozone, one of the strongest oxidants, is an active agent in this method, and reacting with organic compounds, it causes their oxidation. During the first stage of the ozone activity, the bacterial cell wall breaks quickly. Then, residues of polyunsaturated phospholipidderived fatty acids, included in the cytoplasmic membrane, undergo peroxidation, which leads to the formation of superoxides of these compounds. Peroxidation products change physical properties of cell membranes. They cause their depolarisation, inhibiting the activity of both membrane enzymes and transporting proteins. Furthermore, in reactions with strong oxidants, the oxidation of amino acids, proteins, and nucleic acids may also occur. Ozone is a toxic gas for humans, and if inhaled with concentrations in the air beyond a safe value, it can cause serious health problems. Despite ozone's toxic properties, its bacterial, fungal, and viricidal activities are used in ozone therapy in the fields of surgery, dermatology, laryngology, ophthalmology, gynecology, or dentistry. In addition, the synergistic effect of hydrogen peroxide vapor and ozone vapor (referred to in the literature as peroxone and perozone) is used to sterilize heat-sensitive and moisture-sensitive instruments and materials applied in medical care, as a new technology for rapid, low-temperature sterilization, such as 3MTM OptreozTM 125-Z sterilizing system [45]. The therapeutic activity of ozone is comparable to sodium hypochlorite, chlorhexidine, or KTP laser. Bearing in mind the previously discussed susceptibility of SARSCOVID-2 virus, this may be an effective method for air disinfection in dental offices [46, 47].

\section{PROCEDURES IN THE EVENT OF A REASONABLE SUSPICION OF EXPOSURE TO SARS-COV-2}

It is recommended to keep full records of people entering the building, which may constitute a key value to sanitary-epidemiological stations in the event of confirmation of SARS-CoV-2 virus in the facility.

The procedure of choice in a situation of risk of exposure to virus is isolation of the patient and personnel, making a list of people who had been in direct contact with a given person and securing the patient until a decision is made by the Regional Sanitary-Epidemiological Station. The patient should be instructed to wear a surgical mask and follow proper respiratory hygiene procedures, such as covering the mouth and nose with a handkerchief before coughing and sneezing, and then discarding the handkerchief [4].

After transporting a patient suspected of being infected with SARS-CoV-2 coronavirus by medical transport, it is necessary to [23]:

- discontinue the use of the room where the patient was staying, wash and disinfect surfaces, furniture, equipment, and after disinfection, the room can be used again,

- ventilate the room where the patient was staying,

- disinfect the route of the patient's exit from the room (stair handrails, handles, counters, etc., including elements, which may have been touched by the patient),

- determine whether the personnel dealing with the patient was adequately protected and if they had a close contact with the patient (personnel not wearing PPE, but having close contact with an infected patient should be excluded from work until they are informed of the result of the patient's test),

- the District Sanitary-Epidemiological Station (DSES) should be requested for the submission of patient's SARS CoV-2 coronavirus test result (DSES is obliged to provide this information).

\section{FURTHER DENTAL PROCEDURE}

In the case of scheduled treatments, their postponement as well as further check-ups via mobile phone or other video communicators are recommended. In the case of exacerbation of local dental symptoms, depending on the patient's condition and disease manifestation, two types of procedure are recommended:

1. Patients in overall good condition, requiring urgent dental care, suffering from e.g. toothache and/ or edema, should be treated optimally under vacuum (AIRs) [48]. Pharmacological treatment with antibiotics [26] and/or analgesics should be treated as an alternative. This approach may help to alleviate the symptoms and it enables the development of a dental care plan with all appropriate measures in order to prevent the spread of infection. Certain 
limitations are caused by the reports stating a negative impact of bacterial infection and difficulties in antibiotic therapy due to the immune system being weakened by the virus, which may even aggravate the course of the infection and lead to the patient's death [49]. Therefore, causal treatment should be implemented as soon as possible. It should be noted that on March 17, 2020, the "British Medical Journal" recommended the use of paracetamol for pain relief instead of ibuprofen for the treatment of COVID-19-infected patients, since ibuprofen may cause malfunction of the immune system. This recommendation was endorsed by the World Health Organization (WHO) on March 18, 2020 [50].

2. Patients in overall bad condition, requiring urgent dental care, are unlikely to visit the dental office. Dentists, in cooperation with GPs can assess the condition of one's dentition and make an informed decision on providing or postponing the treatment after proper protection supplied by the hospital for infectious diseases. Some cases such as a dentoalveolar trauma or a progressive fascial space infection, strongly justify an emergency dental intervention in hospital wards or other optimal conditions for dental treatment [48]. The decisions concerning the treatment algorithm must be made in consultation with an attending physician [27].

\section{CONCLUSIONS}

The Polish Dental Association recommends urgent admission during an epidemic. This requires proper preparation of dental office and personnel, which is the main goal of our recommendations. The epidemiological situation in the country changes dynamically, but we recommend not to leave our patients without emergency medical aid. We are physicians and we should treat in accordance with our competences.

\section{References}

1. Wax RS, Christian MD. Practical recommendations for critical care and anesthesiology teams caring for novel coronavirus (2019-nCoV) patients. Can J Anaesth 2020; doi: 10.1007/s12630-020-01591-x.

2. Zhou P, Yang XL, Wang XG, Hu B, Zhang L, Zhang W, et al. A pneumonia outbreak associated with a new coronavirus of probable bat origin. Nature 2020; 579: 270-273.

3. Wahba L, Jain N, Fire AZ, Shoura MJ, Artiles KL, McCoy MJ, et al. Identification of a pangolin niche for a 2019-nCoV-like coronavirus through an extensive meta-metagenomic search. bioRxiv 2020; 14 February: 2020.02.08.939660.

4. Wang Y, Wang Y, Chen Y, Qin Q. Unique epidemiological and clinical features of the emerging 2019 novel coronavirus pneumonia (COVID-19) implicate special control measures. J Med Virol 2020; doi: 10.1002/jmv.25748.

5. Hoffmann M, Kleine-Weber H, Schroeder S, Krüger N, Herrler T, Erichsen S, et al. SARS-CoV-2 cell entry depends on ACE2 and TMPRSS2 and is blocked by a clinically proven protease inhibitor. Cell 2020.
6. Jiang F, Deng L, Zhang L, et al. Review of the clinical characteristics of coronavirus disease 2019 (COVID-19). J Gen Intern Med 2020; doi: 10.1007/s11606-020-05762-w.

7. Chan JF, Yuan S, Kok KH, To KK, Chu H, Yang J, et al. A familial cluster of pneumonia associated with the 2019 novel coronavirus indicating person-to-person transmission: a study of a family cluster. Lancet 2020; 395: 514-523.

8. Christiansen GJ. Covid-19: Hype? Hazard? Dental Office Implications? Clin Rep 2020; 13: 1-3.

9. WHO Coronavirus (2019-nCoV). Situation Report 13. WHO 2020.

10. Otter JA, Donskey C, Yezli S, Douthwaite S, Goldenberg SD, Weber DJ. Transmission of SARS and MERS coronaviruses and influenza virus in healthcare settings: the possible role of dry surface contamination. J Hosp Infect 2016; 92: 235e50.

11. Kwok YLA, Gralton J, McLaws ML. Face touching: a frequent habit that has implications for hand hygiene Am J Infect Control 2015; 43: 112-114

12. Lan L, Xu D, Ye G, Xia C, Wang S, Li Y, et al. Positive RT-PCR test results in patients recovered from COVID-19. JAMA 2020: 27; doi: 10.1001/jama.2020.2783.

13. Hoffmann M, Kleine-Weber H, Schroeder S, Mü MA, Drosten C, Pö S, et al. SARS-CoV-2 cell entry depends on ACE2 and TMPRSS2 and is blocked by a clinically proven protease inhibitor. Cell 2020; doi: 10.1016/j.cell.2020.02.052.

14. Sabino-Silva R, Jardim ACG, Siqueira WL. Coronavirus COVID-19 impacts to dentistry and potential salivary diagnosis. Clin Oral Investig 2020; doi: 10.1007/s00784-020-03248-X.

15. Peng X, Xu X, Li Y, Cheng L, Zhou X, Ren B. Transmission routes of 2019-nCoV and controls in dental practice. Int J Oral Sci 2020; 12:9.

16. Neeltje van Doremalen, Trenton Bushmaker, et al. Aerosol and surface stability of SARS-CoV-2 as compared with SARS-CoV-1. N Engl J Med 2020; doi: 10.1056/NEJMc2004973.

17. Sohrabi C, Alsafi Z, O’Neill N, Khan M, Kerwan A, Al-Jabir A, et al. World Health Organisation declares global emergency: a review of the 2019 novel coronavirus (COVID-19). Int J Surg 2020; 76: 71-76.

18. WHO Director-General's opening remarks at the media briefing on COVID-19 - 3 March 2020 [Internet]. Available at: https:// www.who.int/dg/speeches/detail/who-director-general-s-opening-remarks-at-the-media-briefing-on-covid-19---3-march-2020 (Accessed: 11.03.2020).

19. Situation Report-56 SITUATION IN NUMBERS total and new cases in last 24 hours [Internet]. Available at: https://www.who.int/ docs/default-source/coronaviruse/situation-reports/20200316-sitrep-56-covid-19.pdf?sfvrsn=9fda7db2_2 (Accessed: 16.03.2020).

20. Larson EL, Early E, Cloonan P, Sugrue S, Parides M. An organizational climate intervention associated with increased handwashing and decreased nosocomial infections. Behav Med 2000; 26: 14-22.

21. Meng L, Hua F, Bian Z. Coronavirus disease 2019 (COVID-19): emerging and future challenges for dental and oral medicine. J Dent Res 2020; doi.org/10.1177/0022034520914246.

22. Centers for Disease Control recommendations. Available at: https://www.cdc.gov/coronavirus/2019-ncov/prepare/cleaningdisinfection.html?CDC_AA_refVal=https $\% 3 \mathrm{~A} \% 2 \mathrm{~F} \% 2 \mathrm{Fwww}$. cdc.gov\%2Fcoronavirus\%2F2019-ncov\%2Fcommunity\%2Fhome\%2Fcleaning-disinfection.html.

23. https://www.gov.pl/web/koronawirus/komunikat-glownego-inspektora-sanitarnego-w-sprawie-schematu-postepowania-dla-poz-i-nisoz.

24. COVID-19 - zasady postępowania - zalecenia Polskiego Lekarskiego Towarzystwa Radiologicznego i Konsultanta Krajowego w Dziedzinie Radiologii i Diagnostyki Obrazowej. Available at: https://pltr.pl/ wp-content/uploads/2020/03/2020.03.23-COVID-zalecenia -PLTR-1-1.pdf

25. WHO recommendations. Available at: https://apps.who.int/iris/ bitstream/handle/10665/331215/WHO-2019-nCov-IPCPPE use-2020.1-eng.pdf

26. Kaczmarzyk T, Babiuch K, Bołtacz-Rzepkowska E, Dominiak M, Konopka T, Lipski M, et al. Polish Dental Association and National Programme to Protect Antibiotics Working Group recommendations for administration of antibiotics in dentistry. J Stoma 2018; 71: $457-465$ 
27. Zhang J, Zhou L, Yang Y, Peng W, Chen X. Therapeutic and triage strategies for 2019 novel coranovirus disease in fevet clinics. Lancet Respir Med 2020; 8: e11-e12.

28. Rabenau HF, Cinatl J, Morgenstern B, Bauer G, Preiser W, Doerr HW Stability and inactivation of SARS coronavirus. Med Microbiol Immunol 2005; 194: 1-6.

29. Rabenau HF, Kampf G, Cinatl J, Doerr HW. Efficacy of various disinfectants against SARS coronavirus. J Hosp Infect 2005; 61: 107-111.

30. Kampf G, Todt D, Pfaender S, Steinmann E. Persistence of coronaviruses on inanimate surfaces and its inactivation with biocidal agents. J Hosp Infect 2020; 104: 246-251.

31. Pratelli A. Action of disinfectants on canine coronavirus replication in vitro. Zoonoses Publ Health 2007; 54: 383-386.

32. Saknimit M, Inatsuki I, Sugiyama Y, Yagami K. Virucidal efficacy of physico-chemical treatments against coronaviruses and parvoviruses of laboratory animals. Jikken Dobutsu Exp Anim 1988; 37: 341-345.

33. Omidbakhsh N, Sattar SA. Broad-spectrum microbicidal activity, toxicologic assessment, and materials compatibility of a new generation of accelerated hydrogen peroxide-based environmental surface disinfectant. Am J Infect Control 2006; 34: 251-257.

34. Kampf G. Potential role inanimate surfaces for the spread of coronaviruses and their inactivation with disinfectant agents. Infection Prevention in Practice 2020; 2: 100044; doi.org/10.1016/j. infpip.2020.100044.

35. Logothetis DD, Martinez-Welles JM. Reducing bacterial aerosol contamination with a chlorhexidine gluconate pre-rinse. J Am Dent Assoc 1995; 126: 1634-1639.

36. Nicas M, Best D. A study quantifying the hand-to-face contact rate and its potential application to predicting respiratory tract infection. J Occup Environ Hyg 2008; 5: 347-352.

37. Organisational standard of health care in the field of anaesthesiology and intensive care of 29 December 2016 (Journal of Laws, item 2218), status: the act in force, Version effective from: 29 December 2016 and 1 Regulation of the Minister of Health of 16 December 2016.

38. Meng L, Hua F, Bian Z. Coronavirus disease 2019 (COVID-19) emerging and future challenges for dental and oral medicine. J Dental Res 2020; https://doi.org/10.1177/0022034520914246.

39. Source: COVID-19 - zasady postępowania - zalecenia Polskiego Lekarskiego Towarzystwa Radiologicznego i Konsultanta Krajowego w dziedzinie radiologii i diagnostyki obrazowej. Available at: https://pltr.pl/wp-content/uploads/2020/03/2020.03.23-COVIDzalecenia-PLTR-1-1.pdf

40. N95 vs FFP3 \& FFP2 masks - what's the difference? Fast Life Hacks 2020. Available at: https://fastlifehacks.com/n95-vs-ffp/.

41. Kozajda A, Bródka K, Szadkowska-Stańczyk I. Factors influencing biosafety level and lai among the staff of medical laboratories. Medycyna Pracy 2013; 64: 473-486.

42. Janowska M, Polz-Dacewicz M, Prystupa A. Wirus Ebola - przeciwnik stale nieodkryty. Medycyna Ogólna i Nauki o Zdrowiu 2012; 18: 379-382

43. Zielińska-Jankiewicz K, Kozajda A, Szadkowska-Stańczyk I. Zawodowa ekspozycja na czynniki biologiczne i ochrona narażonych na nie pracowników w swietle nowych przepisów prawnych. Medycyna Pracy 2005; 56: 319-323.

44. Filtry HEPA - Vademecum wiedzy o filtrach HEPA, homespot.pl

45. Białoszewski D, Bocian E, Tyski S. Ozonoterapia oraz zastosowanie ozonu w dezynfekcji. Post Microbiol 2012; 51: 177-184.

46. Kuştarci A, Sümer Z, Altunbaş D, Koşum S: Bactericidal effect of KTP laser irradiation against Enterococcus faecalis compared with gaseous ozone: an ex vivo study. Oral Surg Oral Med Oral Pathol Oral Radiol Endod 2009; 107: e73-79.

47. Huth KC, Quirling M, Maier S, Kamereck K, Alkhayer M, Paschos E. Effectiveness of ozone against endontopathogenic microorganisms in a root canal biofilm model. Int Endod J 2009; 42: 3-13.

48. https://doi.org/10.1136/bmj.m1086. World Health Organisation (WHO), 18 March 2020.

49. Ather A, Patel B, Ruparel NB, Diogenes A, Hargreaves KM. Coronavirus Disease 19 (COVID-19): implications for clinical denta care. J Endodont 2020; 46. Available at: https://www.aae.org/specialty/clinical-resources/coronavirus-disease-19-covid-19-implications-for-clinical-dental-care/ .

50. Cheng A. How does coronavirus kill? 2020. Available at: http:// theconversation.com/profiles/allen-cheng-94997. 


\section{APPENDIX}

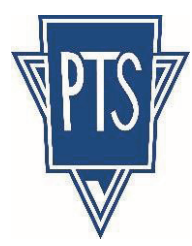

\section{COVID - 19}

\section{infection controls in dental practice}

\section{Patient Evaluation}
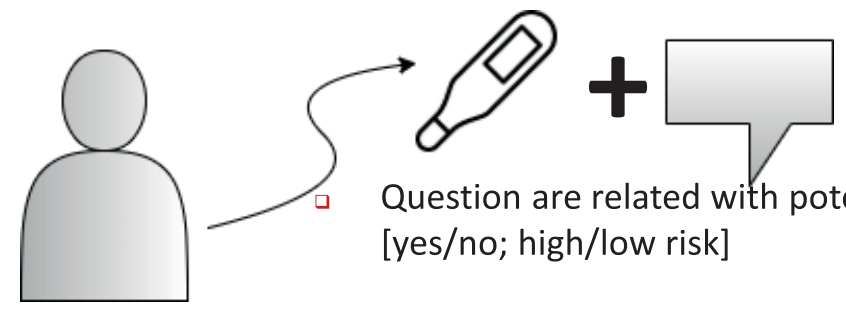

$\square$

Body temperaturę measurement with contact-free forehead thermometer

Question are related with potential exposure to COVID-19 [yes/no; high/low risk]

2. Qualifying the patient for treatment

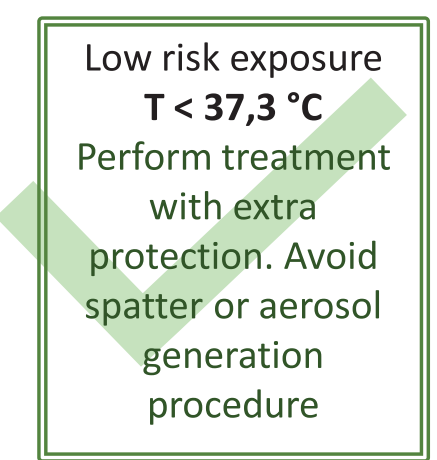

Urgent treatment (tooth trepanation, abscess incision, extraction of the tooth causing the abscess, treatment after trauma)

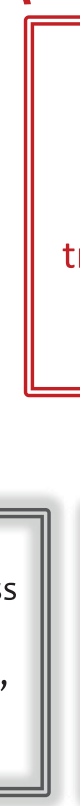

\begin{tabular}{l} 
High risk \\
exposure \\
$\mathbf{T}<\mathbf{3 7 , 3} \mathbf{~}^{\circ} \mathbf{C}$ \\
Postpone \\
eatment until \\
14 days after \\
exposure \\
\hline
\end{tabular}

\begin{tabular}{|c||}
\hline Low risk \\
exposure \\
$\mathbf{T}>\mathbf{3 7 , 3} \mathbf{~}^{\circ} \mathbf{C}$ \\
Refer to \\
hospital for \\
furter \\
examination \\
\hline
\end{tabular}

\section{Dental treatment}

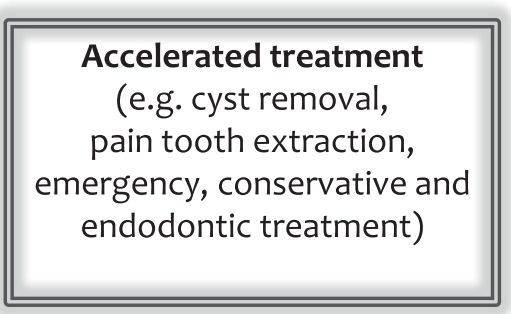

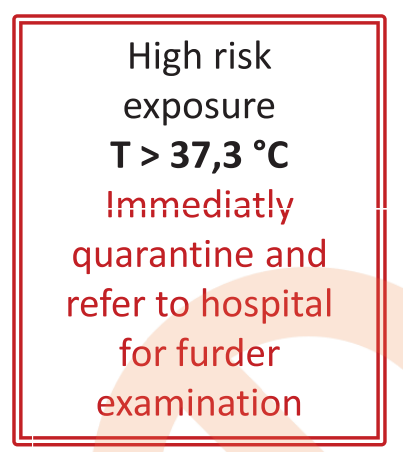

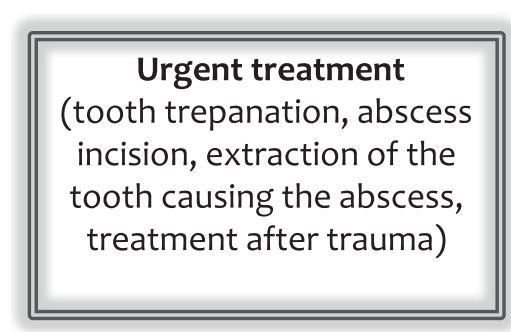

WHO guideline hend hygiene. Two-befor-and-three-after

Hand-washing

Personal Protective Equipment

Mouthrinse befor Dental Procedure

Rubber dam Application

Hand Instruments, High Power Suction

Regular Desinfection

X-ray
Befor: touching patient, aseptic procedure

Afret: body fluids expousure, touching patient, treatment

Disposable hair cover, surgical mask (recommended with HEPA filter), gloves. Coat with disposable isolation clothing or surgical clothes outside. Goggles and face shield.

Reduce salivary microbe loads: $1 \%$ Hydrogen peroxide or $0.2 \%$ Povidine is recommended

To reduce aerosols or spatter

Hand instruments are recommended to reduce aerosol generation

All public areas. Standard disinfection and sterilization for dental clinic. Remember to air the rooms.

Recommended panoramic X-ray or CBCT 